\title{
FOXA1 and IRF-1 intermediary transcriptional regulators of PPAR $\gamma$-induced urothelial cytodifferentiation
}

\author{
CL Varley ${ }^{1}$, EJ Bacon ${ }^{2}$, JC Holder ${ }^{2}$ and J Southgate*,1
}

The peroxisome proliferator-activated receptor $\gamma$ (PPAR $\gamma$ ) is a ligand-activated transcription factor that has been implicated in the induction of differentiation of various cell types, including human uroepithelial cells. PPAR $\gamma$-mediated differentiation of normal human urothelial (NHU) cells in vitro requires coinhibition of epidermal growth factor receptor (EGFR) signalling and is characterised by de novo expression of late/terminal differentiation-associated genes, including uroplakins (UPK), over a 6-day period. We used gene microarrays to identify intermediary transcription factors induced in direct response to PPAR $\gamma$ activation of EGFR-inhibited NHU cells. FOXA1 and IRF-1 contained consensus cognate binding sites in UPK1a, UPK2, and UPK3a promoters and transcripts were induced within $12 \mathrm{~h}$ of PPAR $\gamma$ activation; transcription complex formation was confirmed by electromobility shift assays. In urothelium in situ, both FOXA1 and IRF-1 were nuclear and expressed in a differentiationassociated pattern. Knockdown by transient siRNA of either FOXA1 or IRF-1 abrogated PPAR $\gamma$-induced uroplakin expression in vitro. This is the first evidence that ligand activation of PPAR $\gamma$ induces expression of intermediary transcription factors that mediate an epithelial differentiation programme and represents a new paradigm for understanding differentiation, regenerative repair and inflammation in epithelial tissues.

Cell Death and Differentiation (2009) 16, 103-114; doi:10.1038/cdd.2008.116; published online 8 August 2008

The nuclear receptor, peroxisome proliferator activated receptor $\gamma$ (PPAR $\gamma$ ), heterodimerises with its binding partner, retinoid $\mathrm{X}$ receptor $\alpha(\mathrm{RXR} \alpha)$, to form a ligand-activated transcription factor. Ultimately, the PPAR $\gamma-\mathrm{RXR} \alpha$ complex binds directly to peroxisome proliferator response elements (PPRE) within the promoters of target genes. ${ }^{1}$ PPAR $\gamma$ activation is highly expressed by a number of tissues, including the developing and mature urothelium ${ }^{2-4}$ and is implicated in the induction of differentiation of a number of cell types, including adipocytes ${ }^{5}$ and normal human urothelial (NHU) cells. ${ }^{6,7}$

Urothelium is the transitional epithelium that lines the luminal surface of the bladder and associated urinary tract, where it functions primarily as a urinary barrier. The urothelium is comprised of basal, intermediate and superficial cell zones, which may be distinguished on the basis of differential cytokeratin $(\mathrm{CK})^{8}$ and claudin ${ }^{9}$ isotype expression profiles and by the expression of urothelium-specific uroplakins (UPK) by the superficial cells. ${ }^{10,11}$ Whereas claudins are components of the intercellular tight junctions that determine paracellular barrier function, the uroplakins interact to form characteristic asymmetric unit membrane (AUM) plaques in the superficial apical membrane, which contribute to transcellular barrier function. ${ }^{12}$ Although there has been considerable progress towards understanding the molecular basis of
AUM plaque development, ${ }^{13}$ by contrast, very little is known of the signalling mechanisms that drive the process of urothelial cytodifferentiation.

Urothelium is a mitotically-quiescent epithelium in situ, with a high regenerative capacity. When isolated from the tissue and established in serum-free monolayer culture, cells acquire a highly proliferative 'wound response' phenotype that is driven by an epidermal growth factor receptor (EGFR)dependent autocrine signalling loop. ${ }^{14}$ Based on analysis of CK, claudin and uroplakin expression profiles, NHU cell cultures express a phenotype equivalent to basal/intermediate zone cells in situ and show no evidence of spontaneous late/terminal urothelial cytodifferentiation. ${ }^{9,10,15}$

Previously, we have shown that in EGFR-inhibited $\mathrm{NHU}$ cell cultures, the specific activation of PPAR $\gamma$ results in the induction of a programme of differentiation, leading eventually to de novo expression of late/terminal differentiation markers, including UPK1a, UPK2, UPK3a, CK20 and claudin $3 .{ }^{6,7,9} \mathrm{We}$ proposed that the PPAR $\gamma$-mediated induction of differentiation in NHU cells was indirect for two reasons: (a) the induction of late/terminal differentiation markers was first detected several days after PPAR $\gamma$ activation and only reached a maximum after 4 days and (b) bioinformatics analysis did not identify high-affinity PPRE-binding sites within the upstream promoter regions of the uroplakin, CK13 and CK20 genes. ${ }^{6}$

\footnotetext{
${ }^{1}$ Jack Birch Unit of Molecular Carcinogenesis, Department of Biology, University of York, York Y010 5YW, UK and ${ }^{2}$ GlaxoSmithKline Pharmaceuticals, Ware, Hertfordshire, UK

${ }^{*}$ Corresponding author: J Southgate, Department of Biology, Jack Birch Unit of Molecular Carcinogenesis, University of York, York YO10 5YW, United Kingdom. Tel: + 44 (0) 190432 8705; Fax: + 44 (0) 190432 8704; E-mail: js35@york.ac.uk

Keywords: differentiation; PPAR $\gamma$; interferon regulatory factor; forkhead box; bladder; epithelium

Abbreviations: AUM, asymmetric unit membrane; CK, cytokeratin; NHU, normal human urothelial cells; PPAR $\gamma$, peroxisome proliferator-activated receptor gamma; PPRE, peroxisome proliferator response elements; $\mathrm{RXR} \alpha$, retinoid $\mathrm{X}$ receptor $\alpha$; UPK, uroplakins

Received 21.12.07; revised 12.6.08; accepted 24.6.08; Edited by H Ichijo; published online 08.8.08
} 
Our hypothesis is therefore that activation of PPAR $\gamma$ in urothelial cells leads to production of intermediary transcription factors that entrain the transitional differentiation programme. In this report, we have employed a genechip microarray strategy to identify transcription factor genes induced directly by the PPAR $\gamma$ agonist, troglitazone (TZ) and have investigated two candidate transcription factors with respect to their role in regulating urothelial cytodifferentiation. The results reveal insight into the role of nuclear receptor signalling in epithelial cytodifferentiation and inflammatory processes.

\section{Results}

Regulation of transcription factor expression by TZ and PD153035 in NHU cells. To identify the transcriptional events downstream of PPAR $\gamma$ activation, NHU cells were treated with the synthetic high affinity PPAR $\gamma$ agonist, TZ and the EGFR-specific tyrosine kinase inhibitor, PD153035, and RNA samples were taken for microarray analysis at 12, 24, $48 \mathrm{~h}$. Microarray analysis was also performed on parallel DMSO-treated NHU cell cultures (as vehicle control). The microarray data was analysed to identify genes that were up- or downregulated in TZ and PD153035-treated cells compared with vehicle control cultures at the same time points. We found that of the approximately 12000 gene transcripts represented on the U95Av2 microarray chip, there were 137, 413 and 375 gene transcripts increased in response to $\mathrm{TZ}$ and $\mathrm{PD} 153035$ treatment (greater than signal $\log$ ratio of 1.0 ) at 12,24 and $48 \mathrm{~h}$, respectively, whereas there were 102, 218 and 268 gene transcripts decreased (greater than signal log ratio of -1.0 ) at the same respective time points.

As an internal positive control for the experiment, the microarray data was analysed with respect to the expression of urothelial differentiation-associated genes. This revealed that following treatment of $\mathrm{NHU}$ cell cultures with $\mathrm{TZ}$ and PD153035, differential expression of CK13 and UPK1b transcripts was first detected at $24 \mathrm{~h}$, followed by UPK1a and UPK2 transcripts at $48 \mathrm{~h}$ (Figure 1a).

To test the hypothesis that activation of PPAR $\gamma$ results in transcriptional activation of intermediary transcription factor(s), genes with a signal log ratio of greater than 1.0 (relative to the respective vehicle control) at each time point were clustered by ontology to identify induced transcription
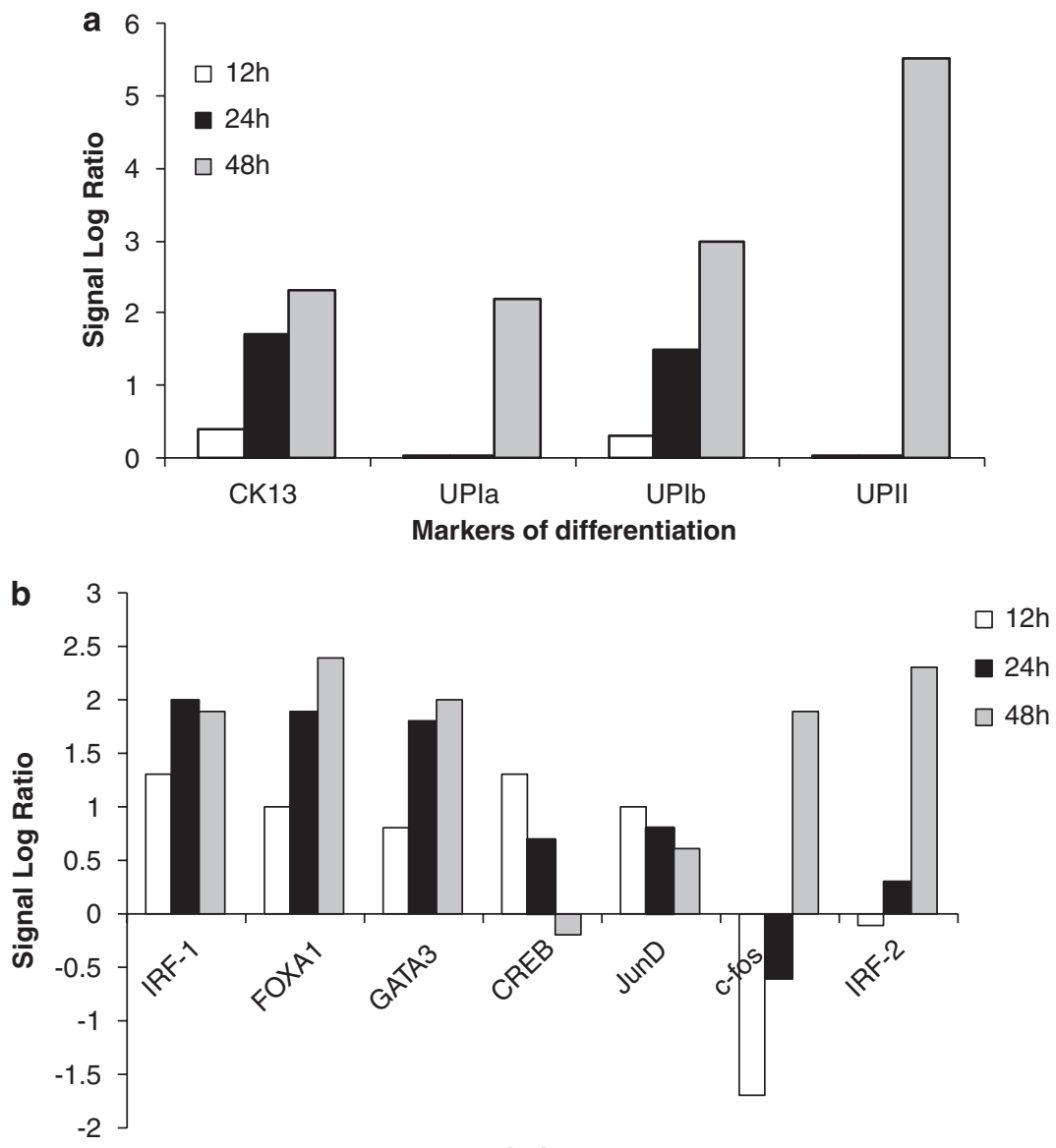

Transcription Factor

Figure 1 Affymetrix genechip array data. NHU cells were treated with or without TZ $(1 \mu \mathrm{M})$ and PD153035 $(1 \mu \mathrm{M})$. RNA was extracted after 12, 24 and $48 \mathrm{~h}$. Biotin-labelled cRNA was generated and hybridised to U95Av2 genechips. (a) Analysis of differentiation-associated marker gene expression in response to treatment with TZ and PD153035, compared with the vehicle-only control. (b) Relative change in expression of transcription factors that recognised predicted binding sites within the promoter regions of urothelial differentiation-associated genes 
Table 1 Changes in transcription factors/activator gene expression identified from microarray gene expression analysis in NHU cells following treatment with TZ and PD153035

\begin{tabular}{|c|c|c|c|}
\hline & \multicolumn{3}{|c|}{ Signal log ratio } \\
\hline & $12 \mathrm{~h}$ & $24 \mathrm{~h}$ & $48 h$ \\
\hline $\begin{array}{l}\text { Upregulated with TZ and PD153035 treatment } \\
\text { Interferon regulatory factor-1 (IRF-1) } \\
\text { Forkhead box A1 (FOXA1) } \\
\text { Ets-related transcription factor } \\
\text { GATA3 for trans-acting T-cell specific transcription factor }{ }^{\mathrm{a}} \\
\text { Forkhead/winged helix-like transcription factor } 7 \text { (FKHL7) } \\
\text { PBX1 } \\
\text { CREB transactivator protein }{ }^{\mathrm{a}} \\
\text { JunD } \\
\text { C-Maf transcription factor } \\
\text { A-type microphthalmia associated transcription factor } \\
\text { Interferon regulatory factor-2 (IRF-2) } \\
\text { Oct-binding factor } \\
\text { Fos proto-oncogene (c-fos) } \\
\text { Nuclear orphan receptor LXR- } \alpha \\
\text { Peroxisome proliferator activated receptor } \gamma \\
\text { Retinoid X receptor } \alpha\end{array}$ & $\begin{array}{c}1.3 \\
1.0 \\
N C \\
N C \\
N C \\
N C \\
1.3 \\
1.0 \\
N C \\
N C \\
N C \\
N C \\
-1.9 \\
N C \\
N C \\
N C\end{array}$ & $\begin{array}{l}2.0 \\
1.9 \\
1.7 \\
1.8 \\
1.8 \\
1.2 \\
\mathrm{NC} \\
\mathrm{NC} \\
1.5 \\
3.4 \\
\mathrm{NC} \\
\mathrm{NC} \\
\mathrm{NC} \\
\mathrm{NC} \\
\mathrm{NC} \\
\mathrm{NC}\end{array}$ & $\begin{array}{c}1.9 \\
2.4 \\
3.2 \\
2.0 \\
2.0 \\
1.3 \\
\mathrm{NC} \\
\mathrm{NC} \\
\mathrm{NC} \\
\mathrm{NC} \\
2.3 \\
1.9 \\
1.9 \\
1.9 \\
1.3 \\
1.0\end{array}$ \\
\hline $\begin{array}{l}\text { Downregulated with TZ and PD153035 treatment } \\
\text { Fos proto-oncogene (c-fos) }{ }^{\mathrm{a}} \\
\text { ETR101 transcription factor } \\
\text { c-Jun proto-oncogene }{ }^{\mathrm{a}} \\
\text { NF-kappa-B } \\
\text { Short form transcription factor C-MAF } \\
\text { STAT4 }\end{array}$ & $\begin{array}{l}-1.9 \\
-1.1 \\
-1.0 \\
\text { NC } \\
\text { NC } \\
\text { NC }\end{array}$ & $\begin{array}{l}\text { NC } \\
\text { NC } \\
\text { NC } \\
\text { NC } \\
\text { NC }\end{array}$ & $\begin{array}{l}1.9 \\
\mathrm{NC} \\
\mathrm{NC} \\
-2.4 \\
-1.7 \\
-1.5\end{array}$ \\
\hline
\end{tabular}

NC, no significant change when compared DMSO-treated cells versus cells treated with TZ and PD153035

a Using bioinformatic analysis these transcription factors/activators have putative binding sites within at least one of the uroplakin gene promoters

factor genes. Sixteen transcription factors were identified and a bioinformatics analysis was performed to identify which of these transcription factors had potential binding sites within the promoter regions of the urothelial differentiation genes (Table 1). This analysis revealed seven candidate transcription factors that were both upregulated by treatment and had predicted binding sites within at least one of the urothelial differentiation-associated gene promoters (Figure $1 \mathrm{~b}$ and Table 1). In addition, there were six transcription factor transcripts that showed decreased expression and of these, $c$-fos, $c$-jun and $N F-\kappa B$ (decreased by 1.9 and 1.0 signal log ratio at $12 \mathrm{~h}$ and by 2.4 signal log ratio at $48 \mathrm{~h}$, respectively) were also found to have predicted binding sites within the urothelial differentiation-associated gene promoter regions (Table 1).

The forkhead box A1 (FOXA1; alternative name: hepatocyte nuclear factor 3- $\alpha$ ) and interferon regulatory factor-1 (IRF-1) transcription factors were selected for further study as they (a) had potential binding sites within two or more of the uroplakin gene promoters (Table 2) and (b) were the only transcription factors that were significantly expressed at all three time points, including the first $12 \mathrm{~h}$ time point, before detection of differentiation marker gene expression. A bioinformatics analysis ${ }^{6}$ predicted that both IRF-1 and FOXA1 had highaffinity PPRE-binding sites in their promoters (1552-1572 and 1307-1327 upstream of the transcriptional start site, respectively). c-Jun was included as a control, as it has previously been shown to be downregulated by PPAR $\gamma$ agonists. ${ }^{18}$

Effect of PPAR $\gamma$ agonists on FOXA1, IRF-1 and c-Jun expression by NHU cells. To confirm the Affymetrix ${ }^{\mathbb{R}}$ genechip results, quantitative RT-PCR was used to determine
Table 2 Potential FOXA and IRF-1 binding sites identified within the $2000 \mathrm{bp}$ sequence upstream of the uroplakin transcriptional start site

\begin{tabular}{lll}
\hline & FOXA $^{\mathrm{a}}$ & IRF-1 \\
\hline UPK1a & None & $429-461$ \\
UPK1b & $1784-1800$ & $1299-1317$ \\
UPK2 & $2263-2279^{\mathrm{b}}$ & $469-487^{\mathrm{c}}$ \\
& $3875-3891^{\mathrm{c}}$ & $1371-1389$ \\
UPK3a & $845-861$ & $1324-1342$ \\
UPK3b & None & $1170-1188$ \\
& & None
\end{tabular}

${ }^{a}$ All FOXA isoforms (FOXA1, FOXA2 and FOXA3) bind a conserved DNAbinding domain ${ }^{16,17}$

bUPK2 had two potential FOXA-binding sites upstream of the transitional start site

${ }^{\mathrm{c} B i n d i n g}$ sites used in the EMSA studies

mRNA expression levels of FOXA1, IRF-1 and c-Jun mRNA in four independent NHU cell lines treated with TZ and PD153035 for periods of up to $48 \mathrm{~h}$. The quantitative RT-PCR results were comparable to the Affymetrix genechip data with FOXA1 and IRF-1 mRNA expression levels induced and c-Jun mRNA expression inhibited by TZ and PD153035 treatments (Figure 2). There was a small increase in IRF-1 mRNA expression when NHU cells were treated with PD153035 alone.

To identify whether these transcript responses were translated to protein, whole protein lysates from NHU cells treated with or without TZ and PD153035 were analysed by immunoblotting to determine relative expression levels of FOXA1, IRF-1 and c-Jun proteins. Expression of FOXA1 protein was only induced when $\mathrm{NHU}$ cells were treated with both TZ and PD153035 (Figure 3a) and the effect was 


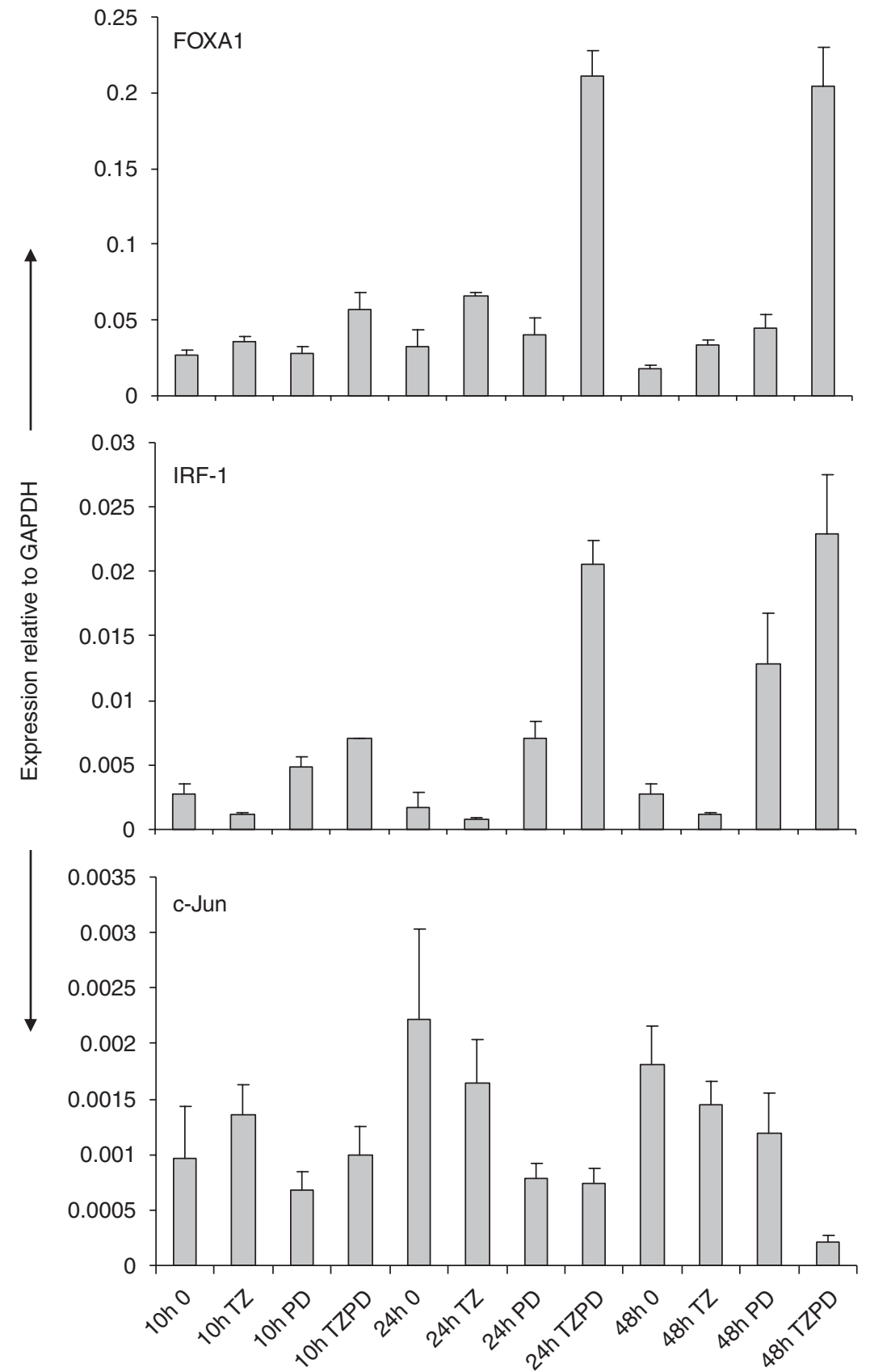

Figure 2 Changes in FOXA1, IRF-1 and c-Jun transcript expression in response to PPAR $\gamma$ activation and EGFR inhibition. NHU cells were treated with or without TZ $(1 \mu \mathrm{M})$ and in the presence or absence of PD153035 $(1 \mu \mathrm{M})$ for the times indicated. RNA was extracted, cDNA generated and absolute quantitative PCR was performed, as outlined in the Materials and Methods. For each datum point there was three replicates and the FAM-labelled FOXA1, IRF-1 or c-Jun product was normalised against the internal control, VIC-labelled GAPDH. This is one of the four experiments performed on independent NHU cell lines all with similar results (Figure 1 in Supplementary Data)

Figure 3 Effect of PPAR $\gamma$ agonists and EGFR inhibition on FOXA1, IRF-1 and c-Jun protein expression in NHU cells. Whole cell lysates were prepared from NHU cells treated as detailed below. Cell extracts $(35 \mu \mathrm{g})$ were resolved on $10 \%$ SDS polyacrylamide gels and transferred onto nitrocellulose membranes. Membranes were incubated with titrated primary antibodies for $16 \mathrm{~h}$ at $4^{\circ} \mathrm{C}$, as indicated. Bound antibody was detected using Alexa Fluor 680 and LI-COR IRDye 800-conjugated secondary antibodies and visualised using the Odyssey Imaging System. $\beta$-actin was used as an internal loading control. These results were reproduced on three independent NHU cell lines. (a) Treated in the absence and presence of TZ $(1 \mu \mathrm{M})$ and with or without PD153035 $(1 \mu \mathrm{M})$ for $32 \mathrm{~h}$. (b) Treated with or without TZ $(1 \mu \mathrm{M})$ in the presence of PD153035 $(1 \mu \mathrm{M})$ and harvested at the times indicated. Fold change was determined by comparing the densitometry values for TZ and PD153035-treated NHU cells to the vehicle control at each time point. (c) Treated with $0-5 \mu \mathrm{M} \mathrm{TZ}$ or RZ in the presence of PD153035 $(1 \mu \mathrm{M})$ for $32 \mathrm{~h}$. (d) Treated with PD153035 and AG1478 in the presence of TZ $(1 \mu \mathrm{M})$ for $32 \mathrm{~h}$ at concentrations indicated. (e) Cells were preincubated with PPAR $\gamma$ antagonist (GW9662 or T0070907) and PD153035 (1 $\mu \mathrm{M})$ for $3 \mathrm{~h}$, before addition of TZ (1 $\mu \mathrm{M})$ for $32 \mathrm{~h}$ 
C
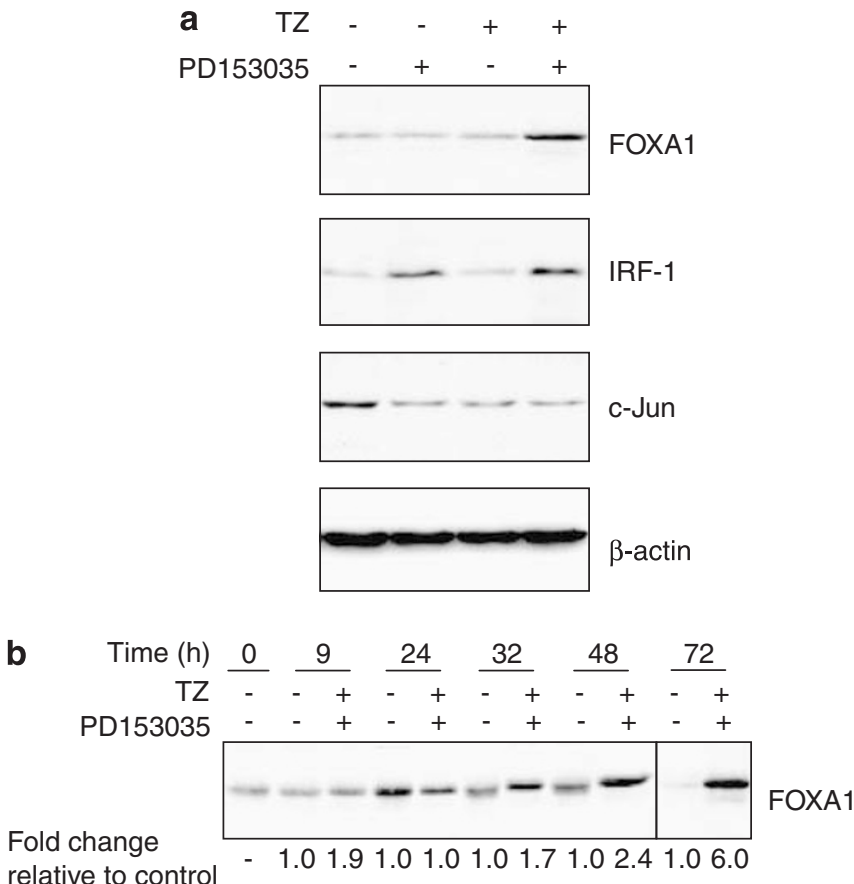
relative to contro

Fold change

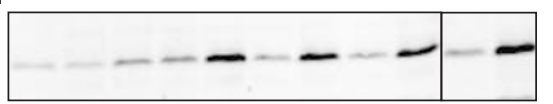
IRF-1 relative to control
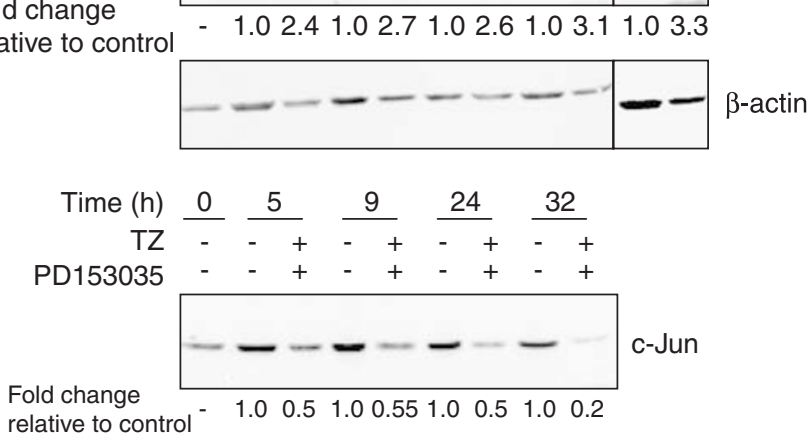

Fold

d change

change

$(\mu \mathrm{M})$

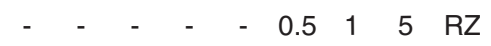

$\begin{array}{lllllllllll}- & - & 0.5 & 1 & 5 & - & - & - & \mathrm{TZ}\end{array}$

-++++++ + PD153035

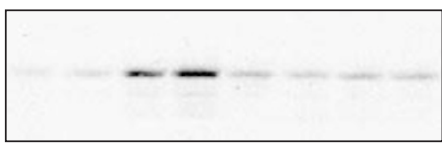

FOXA1

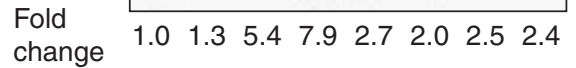

IRF-1 change

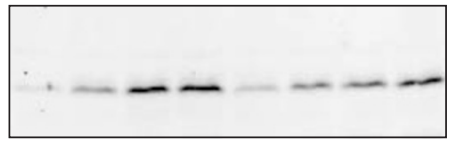

IRF-1

$\begin{array}{llllllll}1.0 & 2.4 & 4.0 & 4.1 & 1.5 & 2.5 & 2.8 & 3.6\end{array}$

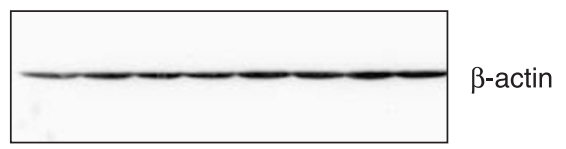

$(\mu \mathrm{M})$

AG1478

-

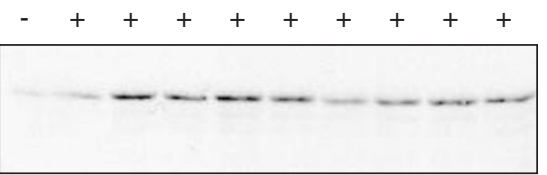

$T Z$

FOXA1

Fold $\quad \begin{array}{lllllllllll}1.0 & 2.9 & 7.3 & 6.0 & 7.8 & 6.7 & 4.4 & 5.6 & 6.3 & 6.0\end{array}$

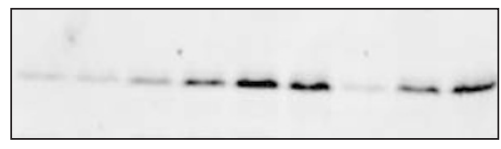

IRF-1

Fold $\quad \begin{array}{lllllllll}1.0 & 1.0 & 1.7 & 2.7 & 4.7 & 4.0 & 0.6 & 2.7 & 3.9\end{array}$

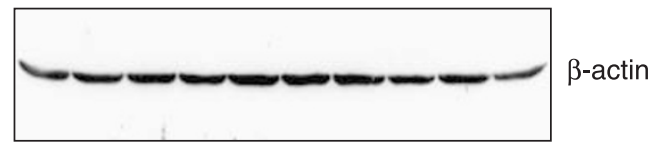

e

$$
\begin{aligned}
& \begin{array}{lllllllllll}
- & - & + & + & + & + & + & + & + & + & \mathrm{TZ} \\
- & + & + & + & + & + & + & + & + & + & \text { PD153035 }
\end{array} \\
& \text { - - - - م. }
\end{aligned}
$$

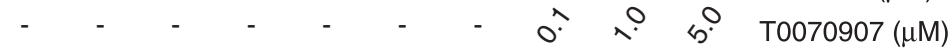

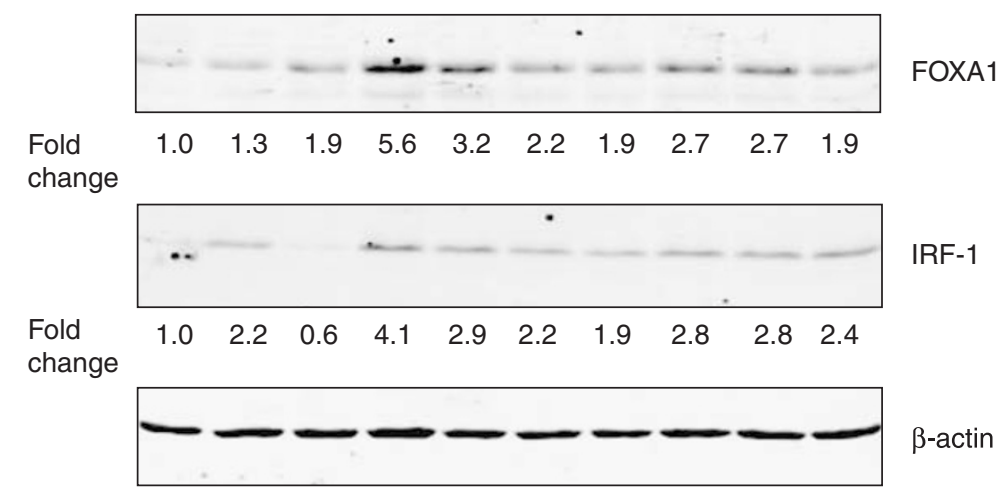


maximal (6-fold above basal) after $72 \mathrm{~h}$ of treatment (Figure 3b). IRF-1 protein expression was induced by treatment of NHU cells with PD153035 alone, but not TZ alone; however, induction was enhanced in the presence of both TZ and PD153035 (Figure 3a). The induction was maximal (3.3-fold) after $72 \mathrm{~h}$ of treatment (Figure $3 \mathrm{~b}$ ), but protein changes were detectable by $24 \mathrm{~h}$ (IRF-1) and $32 \mathrm{~h}$ (FOXA1). The expression of $c$-Jun protein was inhibited by PD153035 or TZ and the effect was greatest at $32 \mathrm{~h}$ after treatment (Figure $3 a$ and $b$ ), in agreement with previous reports that PPAR $\gamma$ agonists inhibit c-Jun. ${ }^{18}$ The effects of TZ and PD153035 on c-Jun were not additive.

TZ increased FOXA1 and IRF-1 protein expression, with maximal effect at $1 \mu \mathrm{M}$ (7.9-fold and 4.1-fold above basal at $32 \mathrm{~h}$, respectively; Figure $3 \mathrm{c}$ ). The results were confirmed using a second PPAR $\gamma$ agonist, rosiglitazone (RZ), which also showed an induction of FOXA1 and IRF-1 protein expression (Figure $3 \mathrm{c}$ ). The induction of FOXA1 and IRF-1 by TZ required that EGFR signalling was inhibited, as confirmed in doseresponse experiments using the EGFR inhibitors, PD153035 and $A G 1478$. These results showed that in the presence of $1 \mu \mathrm{M} \mathrm{TZ}$, the EGFR inhibitors had maximal effects at $1 \mu \mathrm{M}$ PD153035 and $1 \mu \mathrm{M}$ AG1478, respectively (Figure 3d).

To verify that the TZ-induced effect on FOXA1 and IRF-1 was PPAR $\gamma$-specific, NHU cells were stimulated with $\mathrm{TZ}$ and PD153035 in the presence of PPAR $\gamma$ antagonists, GW9662 or T0070907. Both GW9662 and T0070907 had a dosedependent inhibitory effect on induction of FOXA1 (maximal effect approximately $70 \%$ for both inhibitors) and IRF-1 (maximal effect approximately 55 and 42\% for GW9662 and T0070907, respectively; Figure 3e). Notably, the PPAR $\gamma$ antagonists reduced expression of FOXA1 and IRF-1 to the amount induced by PD153035 alone, indicating EGFR signalling may have some involvement in modifying the expression of these transcription factors.

Localisation of FOXA1 and IRF-1 in human urothelium. Immunohistochemical labelling with antibodies against UPK1b and UPK3a confirmed that uroplakin expression was highly restricted to the apical membrane of the superficial urothelium (Figure $4 \mathrm{a}$ and b). FOXA1 was localised to the nuclei of urothelial cells in both bladder and ureter (Figure 4c and $\mathrm{d}$ ) and showed a differentiationassociated distribution, with very little FOXA1 expression detected in the basal cell layer (Figure 4d, arrows) and an increase in the intensity of labelling towards the superficial cells. IRF-1 was less intensely expressed than FOXA1, but again, the localisation was confined to nuclei of the intermediate and superficial urothelial cell layers (Figure 4e), with very little expression detected in the basal cell layer (Figure $4 \mathrm{e}$, arrows). These results demonstrate that FOXA1 and IRF-1 are both expressed by normal human urothelium in situ and show a localisation compatible with a role in differentiation.

\section{Effect of FOXA1 and IRF-1 knockdown on expression} of TZ-PD153035-induced uroplakin genes. Maximal transcript and protein expression of FOXA1 and IRF-1 was apparent when NHU cells were treated with both $\mathrm{TZ}$ and PD153035 and was detectable prior to induction of differentiation-associated gene expression. We therefore used small interfering RNA (siRNA) to individually knockdown FOXA1 and IRF-1 expression to investigate whether FOXA1 and/or IRF-1 was essential for induction of urothelial differentiation in response to PPAR $\gamma$ activation. Preliminary optimisation experiments were performed to
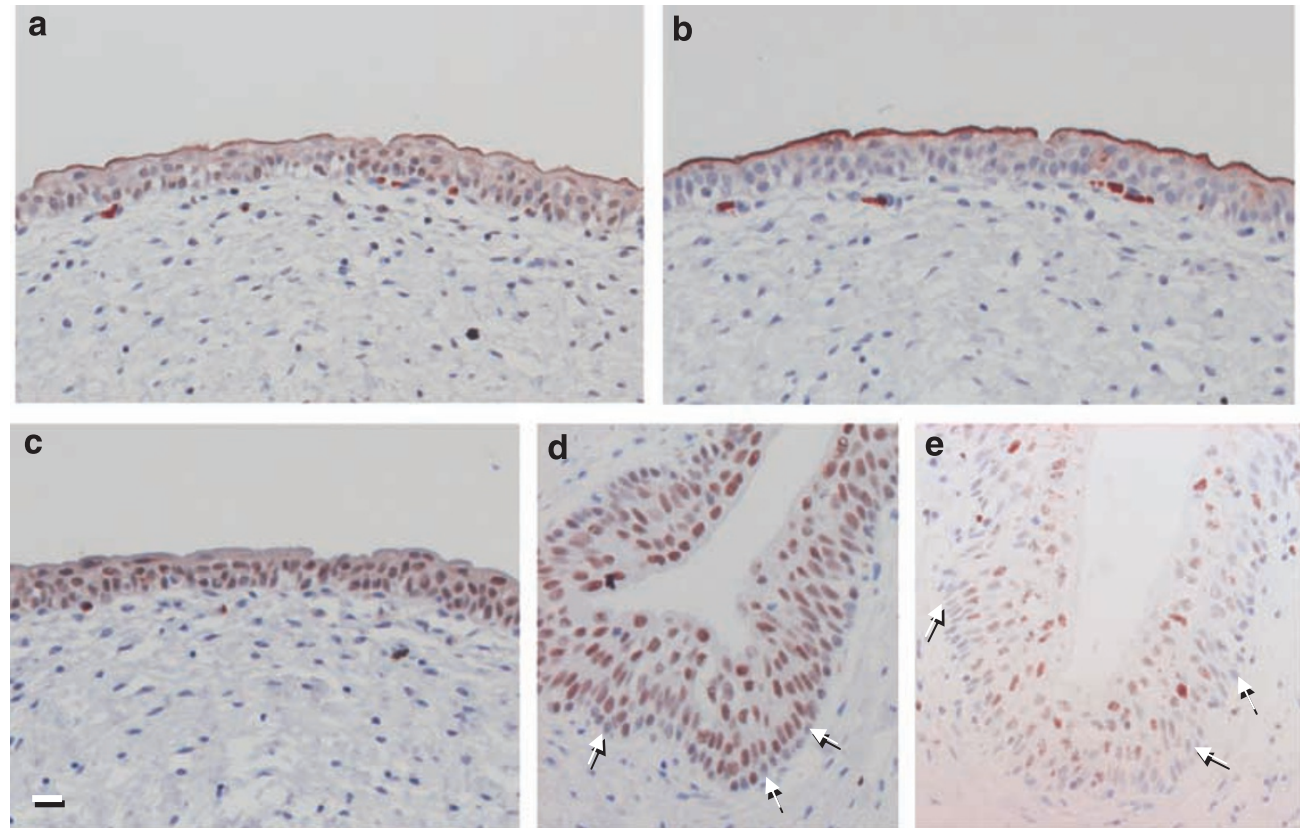

Figure 4 Immunohistochemical expression of FOXA1 and IRF-1 in human bladder and ureter. Immunohistochemical labelling for UPK1b (a) and UPK3a (b) in bladder, FOXA1 in bladder (c) and ureter (d) and IRF-1 in ureter (e). Note that staining of blood vessels represent endogenous peroxidase activity. Scale bar $=20 \mu \mathrm{m}$. Similar results were obtained in bladder and ureter sections from five independent donors (age range, 49-76 years) 

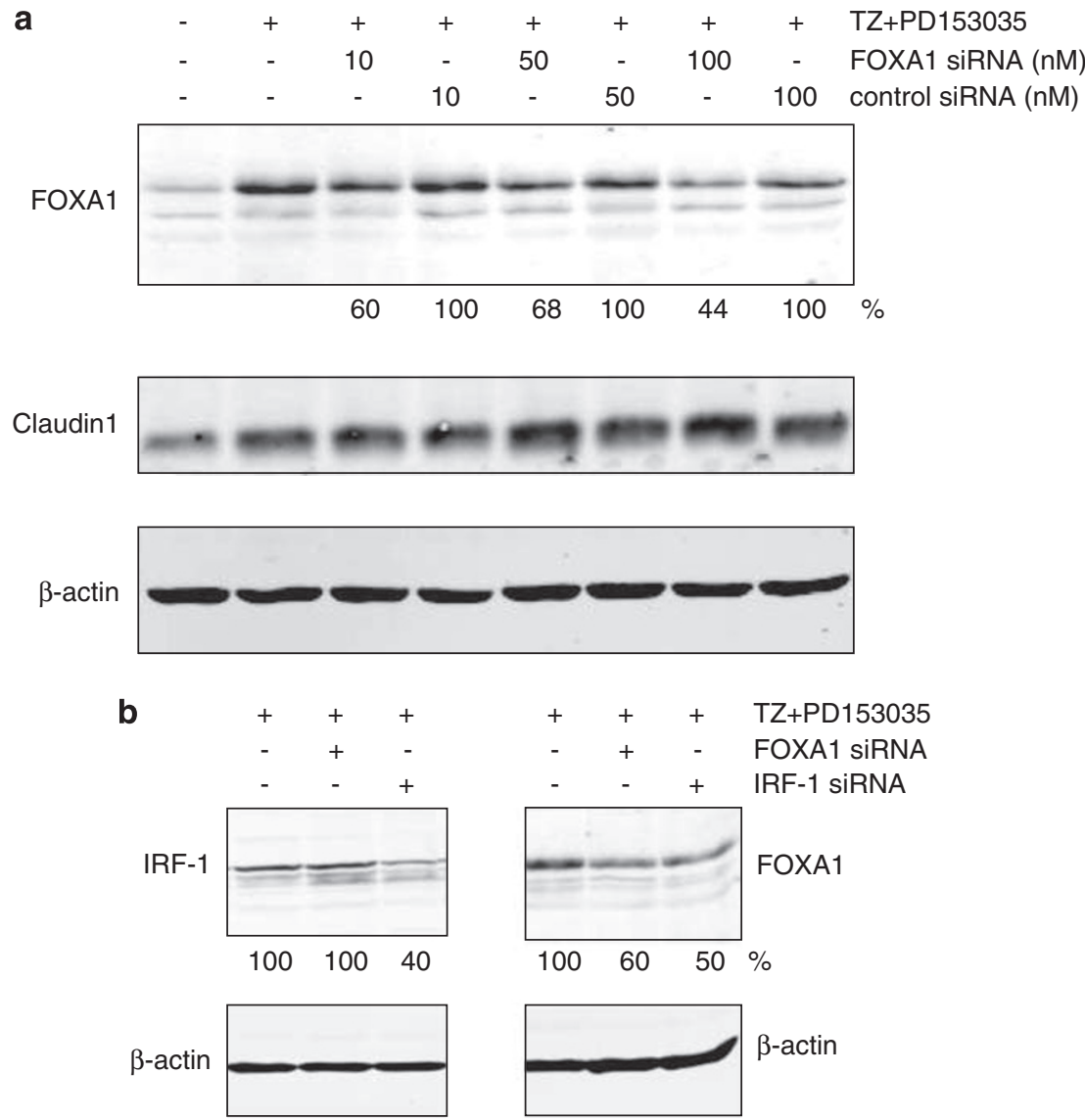

Figure 5 Influence of FOXA1 siRNA and IRF-1 siRNA on the FOXA1 and IRF-1 expression in differentiating NHU cell cultures. (a) NHU cells were transfected with FOXA1 siRNA or the control eGFP siRNA, before the addition of $1 \mu \mathrm{M} \mathrm{TZ}$ and $1 \mu \mathrm{M}$ PD153035. After $46 \mathrm{~h}$, whole cell lysates were prepared from transfected NHU cells and cell extracts $(20 \mu \mathrm{g})$ were assessed by western blot analysis as described in the Materials and Methods. $\beta$-actin was used as an internal loading control. eGFP control siRNA was taken to be $100 \%$. (b) NHU cells were transfected with IRF-1 siRNA (100 nM) or FOXA1 siRNA (100 nM), incubated with TZ and PD153035 for $46 \mathrm{~h}$ and analysed by western blot as outlined above. This is one of two experiments on independent cell lines with similar results

determine conditions required to achieve high transfection efficiencies for siRNA (Figure $2 a$ of Supplementary Information) and showed that when NHU cells were transfected, even the highest concentration of siRNA had no significant effect on NHU cell morphology and viability (Figure $2 \mathrm{~b}$ of Supplementary Information).

Treatment of NHU cells with FOXA1 siRNA reduced the effects of TZ and PD153035 on the induction of FOXA1 protein expression by a maximum of $55 \%$ when compared with the control siRNA (Figure 5a). There was no effect on claudin 1 protein expression, which has previously been shown not to be affected by PPAR $\gamma$ activation. ${ }^{9}$

NHU cells treated with IRF-1 siRNA inhibited the TZ and PD153035-mediated induction of IRF-1 protein expression by $60 \%$ (Figure $5 \mathrm{~b}$ ). The induction of FOXA1 protein by combined treatment with TZ and PD153035 was inhibited by $40 \%$, by siRNA to FOXA1 (Figure 5b). Although FOXA1 siRNA had no effect on IRF-1 protein expression, it was found that IRF-1 siRNA reproducibly downregulated FOXA1 expression. This may be owing to an off-target effect of the siRNA, or could indicate that induction of FOXA1 expression by TZ and PD153035 lies downstream of the induction of IRF-1.
We have demonstrated previously that treatment of $\mathrm{NHU}$ cells with TZ and PD153035 led to de novo transcription of various urothelial differentiation-associated genes/proteins, including claudin $3,{ }^{9} \mathrm{CK} 13^{7}$ and uroplakins. ${ }^{6}$ IRF-1 siRNA decreased claudin 3 and CK13 protein by a maximum of 52 and $62 \%$ of control, respectively (Figure $6 \mathrm{a}$ ) and UPK1a, UPK2 and UPK3a mRNA expression by $70 \%$ (Figure $6 \mathrm{~b}$ ) of control in TZ/PD153035-treated NHU cells. UPK1b mRNA expression was inhibited to a lesser extent, by approximately $20 \%$ and UPK3b mRNA expression was increased by $60 \%$ (Figure 6b). Similar observations were made when NHU cells were treated with FOXA1 siRNA, where there was a reduction of TZ and PD153035-induced expression of claudin 3 (49\%) and CK13 (54\%) protein (Figure 6a) and UPK1a (70\%), UPK2 $(50 \%)$ and UPK3a (20\%) mRNA and slight increases in UPK1b and UPK3b transcripts (Figure 6b).

Influence of TZ and PD153035 on IRF, FOXA and AP-1 complexes associated with the UPK2 promoter. To demonstrate the direct effect of the TZ-PD153035-induced intermediary transcription factors on their target genes electromobility shift assays (EMSA) were performed using predicted consensus-binding sites for IRF-1 IRF, FOXA and 

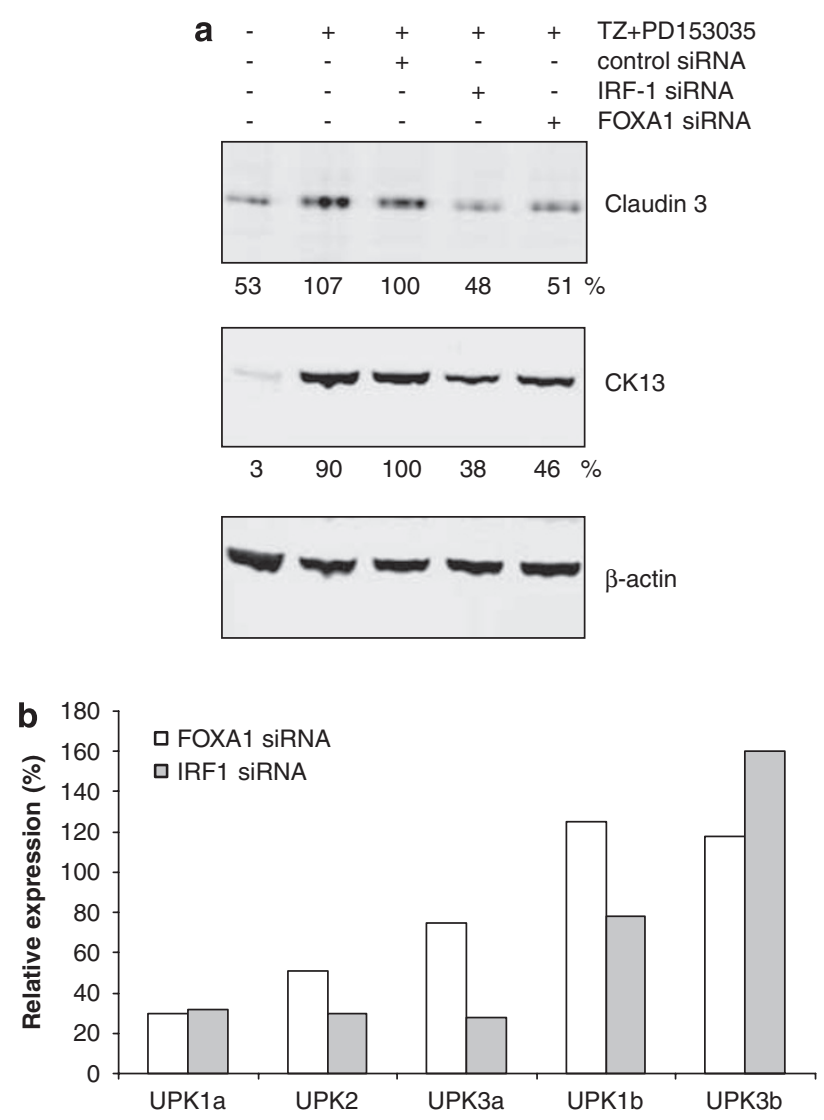

Figure 6 Effect of IRF-1 siRNA and FOXA1 siRNA on expression of differentiation-associated proteins in NHU cell cultures. (a) NHU cells were transfected with IRF-1 siRNA, FOXA siRNA or the Allstars control siRNA followed by the addition of $1 \mu \mathrm{M} \mathrm{TZ}$ and $1 \mu \mathrm{M}$ PD153035. Media containing inhibitors were replenished after 3 days. On day 6 , cell lysates were prepared from the cells and extracts $(20 \mu \mathrm{g})$ were assessed for CK13 and claudin 3 protein expression by western blot analysis as described in the Materials and Methods. The values were normalised against $\beta$-actin and the control siRNA was assigned an arbitrary value of $100 \%$. (b) NHU cells were transfected with and without IRF-1 siRNA (10 nM), FOXA1 siRNA ( $50 \mathrm{nM})$ or the control eGFP siRNA $(50 \mathrm{nM})$ and then incubated with $1 \mu \mathrm{M} \mathrm{TZ}$ and $1 \mu \mathrm{M}$ PD153035. Three days post-transfection, RNA was extracted, cDNA generated and absolute quantitative PCR was performed to determine expression levels of the uroplakins, as outlined in the Materials and Methods. For each datum point, the FAM-labelled uroplakin product was normalised against the internal control, VIC-labelled GAPDH. Data show the mean of three replicates, which were normalised to the control, which was taken as $100 \%$. This is one of the two experiments on independent cell lines with similar results

AP-1 upstream of the UPK2 promoter (Table 2). One IRF and two FOXA-binding complexes were induced when NHU cells were treated with TZ and PD153035 for 30h (Figure 7a and $b$ ). Formation of these complexes were abolished by incubation with the appropriate unlabelled ('cold') IRF or FOXA binding sequence and this effect was reversed when the unlabelled IRF or FOXA were mutated in the consensus region of the oligonucleotide.

To verify the presence of IRF-1 and FOXA1 in their respective complexes, supershift reactions were performed using specific antibodies. The IRF complex was obliterated when anti-IRF-1 was added and the negative control anti-cJun had no effect on the band pattern. This suggests that IRF-1 is the main component of the IRF complex. When anti-
FOXA1 was used the two FOXA-binding complexes were partially disrupted, suggesting that although FOXA1 is in the two complexes it is not the only component.

When EMSAs were performed using the potential AP-1binding site, two AP-1binding complexes were formed, which were disrupted when NHU cells were treated with $\mathrm{TZ}$ and PD153035 (Figure 7c). The complexes were abolished by incubation with the appropriate unlabelled ('cold') AP-1. This result supports the earlier observation that TZ and PD153035 inhibited c-Jun expression in NHU cells and implies that c-Jun is found within AP-1-binding complexes.

\section{Discussion}

This study implicates FOXA1 and IRF-1 as PPAR $\gamma$-regulated intermediary transcription factors involved in mediating the uroepithelial differentiation programme. FOXA1 and IRF-1 gene expression was induced within $12 \mathrm{~h}$ of activating PPAR $\gamma$ in EGFR-inhibited urothelial cells and siRNA knockdown of either FOXA1 or IRF-1 abrogated the PPAR $\gamma$-induced induction of late/terminal urothelial differentiation-associated genes. FOXA1 and IRF-1 both contained consensus PPRE within their promoter regions and both were shown to form specific transcription complexes at UPK2 upstream consensus-binding sites in TZ-PD153035-treated cells. In the context of our previous reports, ${ }^{6,7,9}$ identification of intermediary transcription factors explain both the delay in induction of differentiation-associated gene transcription in response to PPAR $\gamma$ activation and the lack of consensus PPRE-binding sites in the differentiation gene promoters. The results also add weight to our previous findings that EGFR signalling contributes to regulating the proliferative versus differentiated phenotype in urothelium, ${ }^{6,14}$ as induction of IRF-1 and FOXA1 expression in response to $\mathrm{PPAR} \gamma$ activation required blockade of EGFR signalling.

The UPK1a promoter was predicted to have an IRF-1 site, but not a FOXA-binding site, however, expression of UPK1a was inhibited when either FOXA or IRF-1 expression was inhibited. In the quantitative mRNA analysis, it was noted that expression of UPK1a transcripts closely mirrored that of UPK2, implying that there may be a feedback from UPK2 on UPK1a gene transcription. This is perhaps not surprising, as UPK1a and UPK2 proteins form obligate heterodimers as a prerequisite for exit from the endoplasmic reticulum. ${ }^{13}$ However, this implies a difference between human urothelial cells in vitro and mouse urothelium in vivo, as germline ablation of the UPK2 gene led to a two-fold increase in UPK1a and ten-fold increase in UPK1b mRNA, relative to wild-type urothelium. ${ }^{19}$

Although FOXA1 and IRF-1 were both implicated in the PPAR $\gamma$-activated induction of UPK3a transcription, unlike the UPK2/UPK1a partnership, siRNA knockdown of FOXA1 and IRF-1 had only limited consequences for UPK1b expression. However, we also observed increased transcription of UPK3b, which can also heterodimerise with UPK1b and is thought to be expressed at an earlier stage of differentiation than UPK3a. ${ }^{20}$ This suggests differences in the regulation of UPK1b and UPK3b when compared with the other uroplakins, whose expression in man is restricted to terminally differentiated superficial urothelial cells. We have also shown 


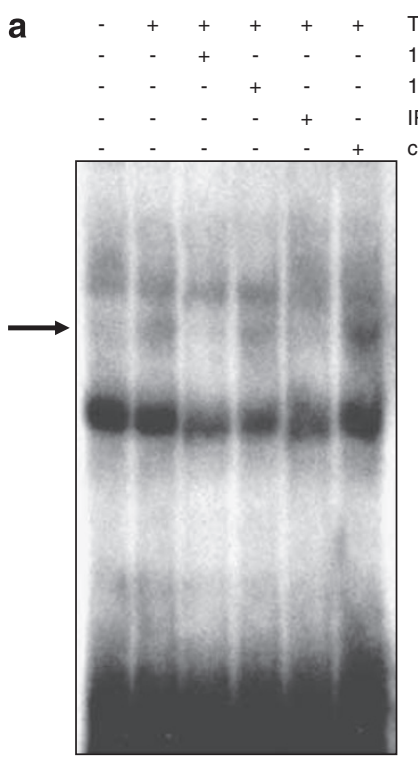

TZ+PD153035

100x 'cold' WT IRF-UPK2

$100 x$ 'cold' mutant IRF-UPK2

RF-1 Ab

C-Jun Ab

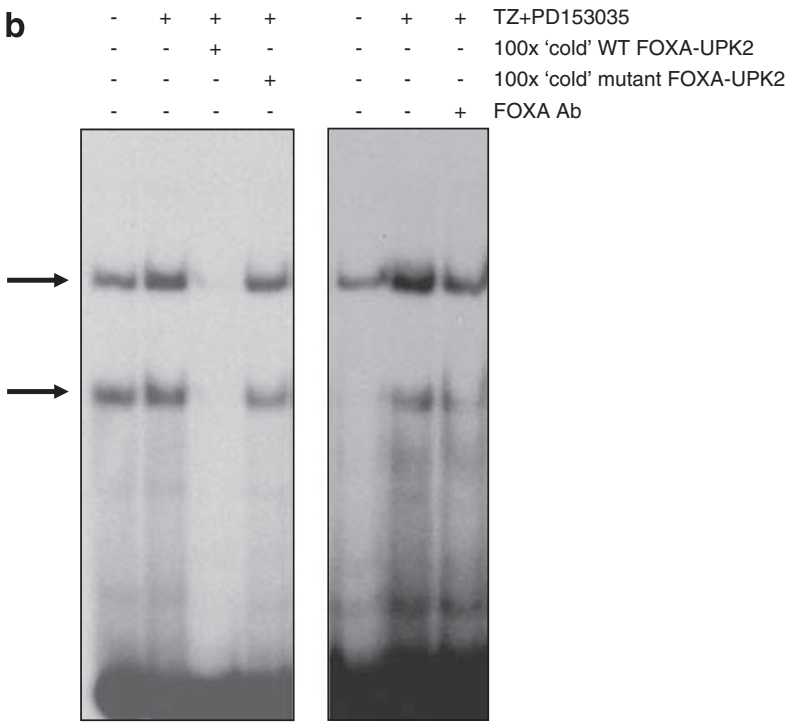

C
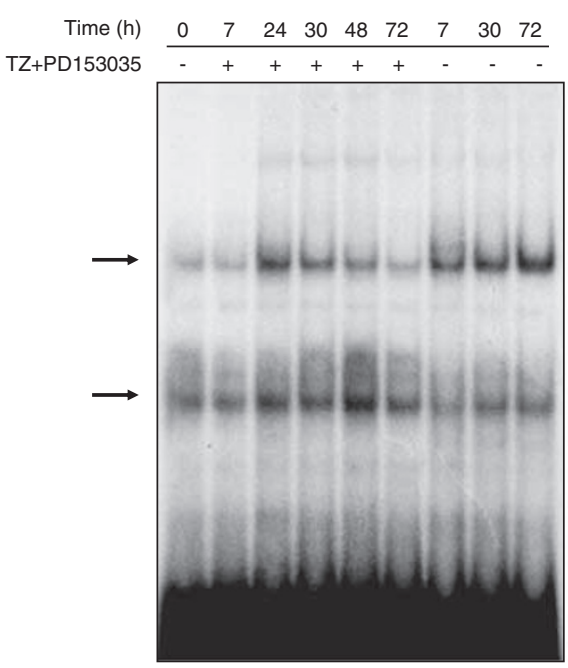

'cold'-AP-1-UPK2
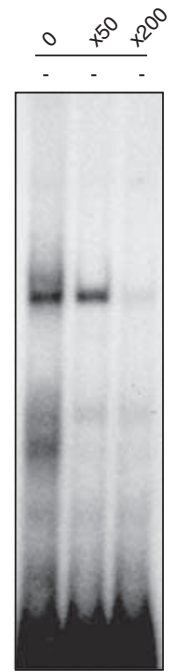

Figure 7 EMSA analysis of the influence of TZ/PD153035 treatment on IRF, FOXA and AP-1 complexes associated with the UPK2 promoter in NHU cells. EMSA was performed with nuclear extracts from NHU cell cultures treated with or without TZ $(1 \mu \mathrm{M})$ and PD153035 (1 $\mu \mathrm{M})$ for $30 \mathrm{~h}$ or as specified for (a) IRF-UPK2, (b) FOXA-UPK2, and (c) AP-1-UPK2. Competition studies were performed using unlabelled mutant and wild-type (WT) oligonucleotides at 50, 100 or 200 fold that of the respective [ $\alpha^{32} P$ ]dATPlabelled oligonucleotide. For supershift EMSA, antibodies were added to the nuclear reaction sample for $20 \mathrm{~min}$ (IRF-1 antibody, $2 \mu \mathrm{g}$ ) or $1 \mathrm{~h} 45 \mathrm{~min}$ (FOXA1 antibody, $4 \mu \mathrm{g}$ ) and incubated at $4^{\circ} \mathrm{C}$ before the addition of the labelled oligonucleotide. Inclusion of c-Jun antibody was included as a control (see a)

previously that only UPK1b gene expression is upregulated by PPAR $\gamma$ activation independently of EGFR signalling. ${ }^{6}$ UPK $1 \mathrm{~b}$ is the least differentiation-restricted of the uroplakins, being expressed by proliferating NHU cells and overexpressed in $50 \%$ superficial urothelial cell carcinomas, suggesting it may have an alternative function in non-differentiated urothelium. $^{10}$

The specific immunolocalisation of both FOXA1 and IRF-1 to the nuclei of suprabasally-positioned urothelial cells in situ is consistent with a role in cytodifferentiation. This is the first report of FOXA1 and IRF-1 localisation in human urothelium, although FOXA1 expression has been demonstrated previously in bladder, prostate and other epithelial tissues in the adult rat, and is expressed throughout the urothelium of the renal pelvis in adult mice ${ }^{21}$ and in the developing mouse lung and bladder. ${ }^{21-23}$ FOXA1 has been proposed to play an important role in the embryonic development and differentiation primarily of endodermally derived tissues, ${ }^{21,24,25}$ including urothelium, ${ }^{44}$ although there is evidence that FOXA1 and FOXA2 are required for mesoderm formation. ${ }^{23}$ Our study showed FOXA1 expression in urothelia from both endodermally derived bladder and mesodermally derived ureter, implying a mutual differentiation process. FOXA1 has been previously reported to be a primary target for all-trans retinoic acid-induced differentiation of mouse F9 and P19 embryonal carcinoma, and Neuro2a neuroblastoma cell lines. ${ }^{26-28}$ However, there has been no previous report that FOXA1 expression is mediated through PPAR $\gamma$ activity. Differentiation of 
preadipocytes to adipocytes is also a PPAR $\gamma$-dependent process, involving a cascade of gene transcription changes. Although FOXA1 has not specifically been implicated as a PPAR $\gamma$-regulated gene in adipogenesis, the expression of lipoprotein lipase, which is one of the first genes induced during adipogenesis, requires a FOXA-binding cis-regulatory factor. $^{29}$

The identification of IRF-1 as a transcriptional regulator of urothelial differentiation was unexpected, as there has been no previous report of IRF-1 expression in the urothelium of any species and it is generally regarded as a transcriptional activator of genes induced by the interferons and other cytokines. Nevertheless, IRF-1 is an essential transcription factor in the regulation of the cornified envelope genes during keratinocyte differentiation ${ }^{30}$ and is a primary response gene in myeloid differentiation. ${ }^{31}$ Conversely, the interferons themselves have been shown to modulate keratinocyte differentiation $^{32}$ and the expression of genes regulating growth and differentiation. ${ }^{33}$ Urothelium, in common with other epithelial tissues, such as skin, is an epithelial barrier tissue, providing a primary barrier defence against pathogens, and playing a role in innate and adaptive immunity through the induced expression of immunoregulatory cytokines and adhesion molecules. ${ }^{34}$ Epithelia are prone to chronic inflammatory conditions characterised by sustained inflammation in the absence of pathogen, epithelial damage and reversal of differentiation, as found in psoriasis of the skin and interstitial cystitis of the bladder. There is evidence indicating that deranged IRF expression in keratinocytes may be responsible, at least in part, for the aberrant proliferation and dedifferentiation of psoriatic epidermis. The thiazolidinediones (TZDs) have been proposed as therapeutic agents for psoriatic conditions because of their ability to inhibit proliferation and promote skin differentiation ${ }^{35}$ and it is conceivable that PPAR $\gamma$-mediated induction of IRF-1 may play a dual role in promoting differentiation and modulating inflammation.

In conclusion, we have shown that PPAR $\gamma$ activation in normal human urothelial cells entrains a programme of gene expression changes involving intermediary transcription factors that include IRF-1 and FOXA1. Questions remain in particular the nature of the PPAR $\gamma$-activating ligand in vivo, as we have shown that this is not a urine-derived factor. ${ }^{36}$ Nevertheless, we suggest these results have implications for epithelial tissue biology and for understanding the aetiopathology and treatment of dysfunctional and chronic inflammatory conditions.

\footnotetext{
Materials and Methods

Materials. Troglitazone (TZ) was provided by Parke-Davis Pharmaceutical Research (Ann Arbor, USA); RZ and GW9662 were provided by GlaxoSmithKline (Worthing, UK). PD153035 and AG1478 were obtained from CalbiochemNovabiochem Biosciences (Nottingham, UK). T0070907 was obtained from Cayman Chemical Co. (supplied by Axxora, Nottingham, UK).

Rabbit polyclonal antibodies against c-Jun (code H-79) and FOXA1 (code D20) for immunoblotting and EMSA were from Santa Cruz (supplied by AutogenBioclear, Calne, UK), while rabbit polyclonal antibody against claudin 3 (PAD Z23.JM) was from Zymed Laboratories Inc. (supplied by Cambridge Bioscience, Cambridge, UK). Monoclonal antibodies IRF-1 (clone 20/IRF-1) and CK13 (clone IC7) used in the immunoblotting and immunohistochemistry were obtained from BD Biosciences (Oxford, UK) and ICN Biomedicals Inc. (Basingstoke, UK), respectively.
}

Affinity-purified rabbit anti-IRF-1 used in the EMSA supershift studies was obtained from Active Motif (Rixensart, Belgium).

Tissues and cell culture. Normal urothelial tissues were obtained with relevant Local Research Ethics Committee approvals and patient consent, as surgical specimens from patients with no history of urothelial malignancy. A representative sample was processed into paraffin wax for immunohistology and the remainder was used to establish finite $\mathrm{NHU}$ cell lines, as described in detail elsewhere. $^{15,37}$

NHU cell lines were maintained in keratinocyte serum-free medium (KSFM) containing BPE and EGF (Invitrogen, Paisley, UK) with $30 \mathrm{ng} / \mathrm{ml}$ cholera toxin (KSFMc) and subcultured as described. ${ }^{15,37}$ Experiments reported here were performed on NHU cell lines between passages 3-5 and, unless stated otherwise, were seeded at $2.10^{4} \mathrm{cell} / \mathrm{s} / \mathrm{cm}^{2}$ and allowed to attain approximately $70 \%$ confluence before treatment with PPAR $\gamma$ ligands and PD153035.

RNA extraction. Cell monolayers were solubilised in Trizo ${ }^{\mathrm{TM}}$ and the RNA was isolated by chloroform extraction and isopropanol precipitation, according to protocol from Invitrogen. The RNA was treated with DNase I (DNA-free ${ }^{T M}$ kit from Ambion, Huntingdon, UK).

Human GeneChip ${ }^{\circledR}$ arrays. cDNA was synthesised using $10 \mu \mathrm{g}$ of total RNA, 100 pmol T7-(dT) ${ }_{24}$ primer and the Superscript ${ }^{\mathrm{TM}}$ first-strand synthesis system and second-strand reaction mix (0.2 mM dNTP, 0.07 units E.coli DNA ligase, 1.1 units E.coli DNA polymerase I, 0.01 units E.coli RNase H, 10 units T4 DNA polymerase), using the manufacturer's protocol (Invitrogen).

Synthesis of biotin-labelled cRNA was performed using the Bioarray ${ }^{\mathrm{TM}}$ Highyield ${ }^{\mathrm{TM}}$ RNA transcript labelling kit (Enzo Life Sciences supplied by Affymetrix). The final labelled cRNA was cleaned using the RNeasy ${ }^{\mathbb{B}}$ mini kit (Qiagen, Crawley $\mathrm{UK}$ ) and $20 \mu \mathrm{g}$ cRNA was fragmented in buffer (33 mM Tris-acetate, $\mathrm{pH} 8.1,83 \mathrm{mM}$ potassium acetate, $25 \mathrm{mM}$ magnesium acetate) at $94^{\circ} \mathrm{C}$ for $35 \mathrm{~min}$. The fragmented cRNA $(15 \mu \mathrm{g})$ was hybridised to the Affymetrix Genechip human genome U95Av2 array by rotation at $45^{\circ} \mathrm{C}$ for $16 \mathrm{~h}$. The Genechip array was washed, labelled with streptavidin phycoerythrin (Molecular Probes, supplied by Cambridge Bioscience UK) followed by biotinylated anti-streptavidin (Vector Laboratories, Peterborough UK) on an Affymetrix Genechip Fluidics station 400, scanned and analysed using the Affymetrix Microarray Suite. A signal log ratio of 1.0 or less than -1.0 , respectively, was used to identify genes increased or decreased in comparison to the vehicle-only control for each time point.

Real-time RT-PCR. CDNA was synthesised from $1 \mu \mathrm{g}$ total RNA and the Superscript first-strand synthesis system, as above. Quantitative real-time PCR was performed using TaqMan real-time PCR primers and probes designed using the Primer Express Software (Applied Biosystems, Warrington UK), for c-Jun (5'-CGGAGAGGAAGCGCATGA-3'; 5'-CCAGCCGGGCGATTC-3'; probe 5'-CTG CCTCCAAGTGCCGAAAAAGGAAG-3'), FOXA1 (5'- CAAGAGTTGCTTGACCGA AAGTT-3'; 5'-TGTTCCCAGGGCCATCTGT-3'; probe 5'-AGGACCCCAACCCC TTTGCTCTCTACC- $\left.3^{\prime}\right)$ and IRF-1 (5'-TGCATTTATTTATACAGTGCCTTGCT-3'; 5'-CCCTCCCTGGGCCTGTT- $3^{\prime}$; probe 5'-CACCACCCCCTCAAGCCCCA-3') and previously, uroplakins and GAPDH. ${ }^{38}$

The reactions were performed in TaqMan Universal PCR master mix with $300 \mathrm{nM}$ of primers and $200 \mathrm{nM}$ of probe on an ABI Prism 7700 Sequence Detector system (from Applied Biosystems) for $10 \mathrm{~min}$ at $95^{\circ} \mathrm{C}$ followed by 40 cycles of $15 \mathrm{~s}$ at $95^{\circ} \mathrm{C}$ and $60 \mathrm{~s}$ at $60^{\circ} \mathrm{C}$. The data was analysed using the ABI Prism 7700 SDS software. For each data point, the FAM-labelled product was normalised to the VIC-labelled GAPDH internal control.

Promoter analysis. The transcriptional start site for each uroplakin and transcription factor gene was retrieved from NCBI (www.ncbi.nlm.nih.gov), or the literature 39-41, and linked to UCSC Genome Browser (http://genome.ucsc.edu). The NCBI accession codes were: UPK1a, NM007000; UPK1b, NM006952; UPK2, NM006760; UPK3a, NM006953; UPK3b, NM030570; FOXA1, NM004496; IRF-1, NM002198 and c-Jun, NM_002228. A $2 \mathrm{~kb}$ region upstream of the transcriptional start site for each uroplakin gene (UPK1a; ${ }^{39}$ UPK $1 b ;{ }^{40}$ UPK2 $;{ }^{41}$ UPK3a and UPK3b predicted from NCBI) was analysed for predicted transcription factor-binding sites using the Matlnspector programme of Genomatix suite. ${ }^{42}$ This was correlated to transcription factors identified from the microarray analysis. 
Table 3 siRNA oligonucleotide templates

\begin{tabular}{|c|c|}
\hline $\begin{array}{l}\text { FOXA1 } \\
\text { (NM004496) }\end{array}$ & \\
\hline Target 1 & $\begin{array}{l}\text { Sense } 5^{\prime} \text {-AATAGAGCCGTAAGGCGAGTACCTGTC } \\
\text { TC- } 3^{\prime} \\
\text { Antisense 5'-AATACTCGCCTTACGGCTCTACCTGTC } \\
\text { TC- } 3^{\prime}\end{array}$ \\
\hline Target 2 & $\begin{array}{l}\text { Sense 5'-AACATGTAGGTGTTCATGGAGCCTGTCT } \\
\text { C- } 3^{\prime} \\
\text { Antisense 5'-AACTCCATGAACACCTACATGCCTGTC } \\
\text { TC- } 3^{\prime}\end{array}$ \\
\hline Target 3 & $\begin{array}{l}\text { Sense 5'-AACACCTTGACGAAGCAGTCACCTGTCT } \\
\text { C-3' } \\
\text { Antisense 5'-AATGACTGCTTCGTCAAGGTGCCTGT } \\
\text { CTC-3' }\end{array}$ \\
\hline & $\begin{array}{l}\text { Sense 5'-AAGGACGACGGCAACTACAAGCCTGTCT } \\
\text { C-3' } \\
\text { Antisense 5'-AACTTGTAGTTGCCGTCGTCCCCTGT } \\
\text { CTC-3' }\end{array}$ \\
\hline $\begin{array}{l}\text { IRF-1 } \\
\text { (NM00 }\end{array}$ & \\
\hline Target 1 & $\begin{array}{l}\text { Sense 5'-AACTTGTTCCTGCTCTGGTCTCCTGTCT } \\
\text { C-3' } \\
\text { Antisense 5'-AAAGACCAGAGCAGGAACAAGCCTGT } \\
\text { CTC-3'; }\end{array}$ \\
\hline Target 2 & $\begin{array}{l}\text { Sense 5'-AACATCCTCATCTGTTGTAGCCCTGTCT } \\
\text { C-3' } \\
\text { Antisense 5'-AAGCTACAACAGATGAGGATGCCTGT } \\
\text { CTC-3' }\end{array}$ \\
\hline Target 3 & $\begin{array}{l}\text { Sense 5'-AACTGGTCTCAGAACCTCATCCCTGTCT } \\
\text { C-3' } \\
\text { Antisense 5'-AAGATGAGGTTCTGAGACCAGCCTGT } \\
\text { CTC-3' }\end{array}$ \\
\hline
\end{tabular}

Matlnspector and a previously described PPAR $\gamma$-defined PPRE matrix ${ }^{6}$ was used to identify PPAR $\gamma$-specific PPRE-binding sites within a $2 \mathrm{~kb}$ region upstream of the transcriptional start site for FOXA1 and IRF-1 genes.

Immunohistochemistry. Immunohistochemistry was performed on $5 \mu \mathrm{m}$ paraffin wax-embedded tissue sections. ${ }^{7}$ Briefly, sections were treated to block endogenous biotin and antigen retrieval was performed by boiling sections for $10 \mathrm{~min}$ in $10 \mathrm{mM}$ citric acid buffer, $\mathrm{pH}$ 6.0. After overnight incubation in primary antibody at $4^{\circ} \mathrm{C}$ slides were washed, incubated in biotinylated secondary antibodies and a streptavidin-biotin horseradish peroxidase complex (Dako Cytomation, Ely, UK) and visualised using a diaminobenzidine substrate reaction (Sigma-Aldrich, Poole, UK). The sections were counterstained with haemotoxylin (Sigma-Aldrich).

Immunoblotting. Cell lysates were prepared as described previously using lysis buffer $(25 \mathrm{mM}$ Hepes $\mathrm{pH} 7.4,125 \mathrm{mM} \mathrm{NaCl}, 10 \mathrm{mM} \mathrm{NaF}, 10 \mathrm{mM}$ sodium orthovanadate, $10 \mathrm{mM}$ sodium pyrophosphate, $0.2 \%$ (w/v) SDS, $0.5 \%$ (w/v) sodium deoxycholate acid, $1 \%$ (w/v) Triton X-100, $1 \mu \mathrm{g} / \mathrm{ml}$ aprotinin, $10 \mu \mathrm{g} / \mathrm{ml}$ leupeptin and $100 \mu \mathrm{g} / \mathrm{ml}$ phenylmethylsulphonyl fluoride) and shearing the lysates through a 21-G needle, incubating on ice for $30 \mathrm{~min}$, before microcentrifugation at $10000 \mathrm{~g}$ for $30 \mathrm{~min}$ at $4^{\circ} \mathrm{C} .^{6}$ The protein concentrations of supernatants were measured by Coomassie assay (Pierce, supplied by Perbio Science UK Ltd., Cheshire, UK). Cell extracts were resolved on $10 \%$ SDS polyacrylamide gels and transferred onto nitrocellulose membranes. Membranes were incubated with titrated primary antibodies for $16 \mathrm{~h}$ at $4^{\circ} \mathrm{C}$. Bound antibody was detected using Alexa Fluor ${ }^{\circledR} 680$ and LI-COR IRDye ${ }^{\mathrm{TM}} 800$ conjugated secondary antibodies and visualised using the Odyssey $^{\mathrm{TM}}$ Imaging System (LI-COR Biosciences UK Ltd., Cambridge).

SiRNA. siRNA templates were designed to three regions of FOXA1 (NM004496) and IRF-1 (NM002198) and to one region of the control eGFP using the Ambion siRNA template design tool (www.ambion.com); sequences are shown in Table 3. The templates were used to generate FOXA1, IRF-1 and eGFP siRNA complexes using the protocol for the Silencer ${ }^{\mathrm{TM}}$ siRNA construction kit (Ambion). The Allstars ${ }^{\mathrm{TM}}$ negative control was obtained from Qiagen Ltd. (Crawley, West Sussex, UK).

For transfections, NHU cells were seeded at $4 \times 10^{5}$ cells $/ \mathrm{ml}$ onto 6 -well Primaria ${ }^{\mathbb{R}}$ plates (Becton-Dickinson) and incubated for $16 \mathrm{~h}$ until approximately $50 \%$ confluent. An equimolar cocktail mixture of the three target siRNAs for FOXA1, IRF-1 or an equivalent concentration of eGFP siRNA or Allstars ${ }^{\mathrm{TM}}$ SiRNA was incubated with Oligofectamine ${ }^{\mathrm{TM}}$ reagent (Invitrogen) in KSFM at ambient temperature for $20 \mathrm{~min}$. The cells were washed with KSFM and the siRNA mixture was added to the cells. After $7 \mathrm{~h}$ incubation at $37^{\circ} \mathrm{C}$ cells were treated with $\mathrm{TZ}$ $(1 \mu \mathrm{M}), \mathrm{PD} 153035(1 \mu \mathrm{M})$ in KSFMc and protein and RNA were extracted after $46 \mathrm{~h}$ and $72 \mathrm{~h}$, respectively. As a control, cells were incubated with transfection agent, Oligofectamine ${ }^{\mathrm{TM}}$ alone in the presence or absence of TZ and PD153035.

Electromobility shift assay. Nuclei were isolated from NHU cells, as previously described. ${ }^{43}$ Briefly, NHU cell cultures were lysed in $10 \mathrm{mM}$ Tris- $\mathrm{HCl}, \mathrm{pH}$ 7.4 containing $10 \mathrm{mM} \mathrm{NaCl}, 3 \mathrm{mM} \mathrm{MgCl}_{2}$ and $0.5 \%$ (v/v) Nonidet P-40. Lysates were incubated for $15 \mathrm{~min}$ on ice and centrifuged at $1000 \mathrm{~g}$ for $5 \mathrm{~min}$ at $4^{\circ} \mathrm{C}$. The pellets were washed in lysis buffer and resuspended in $1 \mathrm{ml}$ nuclear suspension buffer (50 mM Tris- $\mathrm{HCl}$, pH 7.5 containing $10 \mathrm{mM}$ magnesium acetate, $40 \%$ (v/v) glycerol, $1 \mathrm{mM}$ DTT). Nuclei were centrifuged at $1000 \mathrm{~g}$ for $10 \mathrm{~min}$ and nuclear proteins were extracted from the pellet by incubation on ice for $15 \mathrm{~min}$ in extraction buffer $(10 \mathrm{mM}$ HEPES pH 7.5 containing $0.4 \mathrm{M} \mathrm{NaCl}, 5 \mathrm{mM}$ EDTA, $0.2 \mathrm{mM} \mathrm{PMSF}, 1 \mathrm{mM} \mathrm{DTT}$ ), and centrifuged as above. After the addition of glycerol $(15 \%)(\mathrm{v} / \mathrm{v})$ the nuclear extracts were snap-frozen and stored at $-80^{\circ} \mathrm{C}$.

Ten micrograms of nuclear extract was incubated at $4^{\circ} \mathrm{C}$ for 20 min with $3 \mu \mathrm{g}$ poly(dl-dC), $2 \mu \mathrm{l}$ carrier mix (50 mM MgCl 2 and $340 \mathrm{mM} \mathrm{KCl}$ ) and delta buffer (25 mM HEPES pH 7.6 containing $0.1 \mathrm{mM}$ EDTA, $40 \mathrm{mM} \mathrm{KCl}, 8 \%$ (w/v) Ficoll and $1 \mathrm{mM}$ DTT) to give a final volume of $18 \mu \mathrm{l}$. The double-stranded oligonucleotide was labelled with $\left[\alpha^{32} \mathrm{P}\right] \mathrm{dATP}$ using the Random primers DNA labelling system (Invitrogen) and added to the reaction mixture (100000 c.p.m./reaction) and incubated for $30 \mathrm{~min}$ at $4{ }^{\circ} \mathrm{C}$. The samples were resolved on a non-denaturing $5 \%$ polyacrylamide gel at $200 \mathrm{~V}$ for $3 \mathrm{~h}$, dried and exposed to film. For supershift analyses, conditions were optimised for each antibody and the appropriate antibody was incubated at $4{ }^{\circ} \mathrm{C}$ with the nuclear extract reactions before the addition of the labelled oligonucleotide. The sequences for the double-stranded oligonucleotides were predicted from the UPK2 upstream sequence using Genomatrix or Alibaba software (Table 2) and the oligonucleotide sequences used IRF-UPK2 5'-CATTCGCAAGAATTGAAACCCGA-3'; FOXA-UPK2 5'-CATTCGATGAAATAA AAAATGGCGC-3'; AP-1-UPK2 $5^{\prime}$-TCGATTACTGGTTGCTGCTA-3'. Mutants were constructed by scrambling the core consensus regions, mIRF-UPK2 5'-CATTCGCAATACTTCTGACCCGA-3'; mFOXA-UPK2 5'-CATTCGATGAAACG TCAAATGGCGC-3'.

Acknowledgements. This study was funded by York Against Cancer. We are grateful to our clinical colleagues who supplied tissue for the research and to Ms Elaine Davies, Ms Jennifer Hinley and Ms Claire J Weekes for technical assistance.

1. Blanquart C, Barbier O, Fruchart JC, Staels B, Glineur C. Peroxisome proliferator-activated receptors: regulation of transcriptional activities and roles in inflammation. J Steroid Biochem Mol Biol 2003; 85: 267-273.

2. Guan $Y$, Zhang $Y$, Davis L, Breyer MD. Expression of peroxisome proliferator-activated receptors in urinary tract of rabbits and humans. Am J Physiol 1997; 273: F1013-F1022.

3. Jain S, Pulikuri S, Zhu Y, Qi C, Kanwar YS, Yeldandi AV et al. Differential expression of the peroxisome proliferator-activated receptor gamma (PPARgamma) and its coactivators steroid receptor coactivator-1 and PPAR-binding protein PBP in the brown fat, urinary bladder, colon, and breast of the mouse. Am J Pathol 1998; 153: 349-354.

4. Kawakami S, Arai G, Hayashi T, Fujii Y, Xia G, Kageyama Y et al. PPARgamma ligands suppress proliferation of human urothelial basal cells in vitro. J Cell Physiol 2002; 191: 310-319.

5. Lowell BB. PPARgamma: an essential regulator of adipogenesis and modulator of fat cell function. Cell 1999; 99: 239-242.

6. Varley CL, Stahlschmidt J, Lee WC, Holder J, Diggle C, Selby PJ et al. Role of PPARgamma and EGFR signalling in the urothelial terminal differentiation programme. J Cell Sci 2004; 117: 2029-2036.

7. Varley $\mathrm{CL}$, Stahlschmidt J, Smith B, Stower M, Southgate J. Activation of peroxisome proliferator-activated receptor-gamma reverses squamous metaplasia and induces transitional differentiation in normal human urothelial cells. Am J Pathol 2004; 164 : 1789-1798. 
8. Southgate J, Harnden P, Trejdosiewicz LK. Cytokeratin expression patterns in normal and malignant urothelium: a review of the biological and diagnostic implications. Histol Histopathol 1999; 14: 657-664.

9. Varley CL, Garthwaite MA, Cross W, Hinley J, Trejdosiewicz LK, Southgate J. PPARgamma-regulated tight junction development during human urothelia cytodifferentiation. J Cell Physiol 2006; 208: 407-417.

10. Lobban ED, Smith BA, Hall GD, Harnden P, Roberts P, Selby PJ et al. Uroplakin gene expression by normal and neoplastic human urothelium. Am J Pathol 1998; 153 1957-1967.

11. Olsburgh J, Harnden P, Weeks R, Smith B, Joyce A, Hall G et al. Uroplakin gene expression in normal human tissues and locally advanced bladder cancer. J Pathol 2003; 199: $41-49$.

12. Hu $P$, Deng FM, Liang FX, Hu CM, Auerbach $A B$, Shapiro E et al. Ablation of uroplakin III gene results in small urothelial plaques, urothelial leakage, and vesicoureteral reflux. J Cell Biol 2000; 151: 961-972.

13. Tu L, Sun TT, Kreibich G. Specific heterodimer formation is a prerequisite for uroplakins to exit from the endoplasmic reticulum. Mol Biol Cell 2002; 13: 4221-4230.

14. Varley C, Hill G, Pellegrin S, Shaw NJ, Selby PJ, Trejdosiewicz LK et al. Autocrine regulation of human urothelial cell proliferation and migration during regenerative responses in vitro. Exp Cell Res 2005; 306: 216-229.

15. Southgate J, Hutton KA, Thomas DF, Trejdosiewicz LK. Normal human urothelial cells in vitro: proliferation and induction of stratification. Lab Invest 1994; 71: 583-594.

16. Duncan SA, Navas MA, Dufort D, Rossant J, Stoffel M. Regulation of a transcription factor network required for differentiation and metabolism. Science 1998; 281: 692-695.

17. Lai E, Prezioso VR, Tao WF, Chen WS, Darnell Jr JE. Hepatocyte nuclear factor 3 alpha belongs to a gene family in mammals that is homologous to the Drosophila homeotic gene fork head. Genes Dev 1991; 5: 416-427.

18. Subbaramaiah K, Lin DT, Hart JC, Dannenberg AJ. Peroxisome proliferator-activated receptor gamma ligands suppress the transcriptional activation of cyclooxygenase-2. Evidence for involvement of activator protein-1 and CREB-binding protein/p300. J Biol Chem 2001; 276: 12440-12448.

19. Kong XT, Deng FM, Hu P, Liang FX, Zhou G, Auerbach AB et al. Roles of uroplakins in plaque formation, umbrella cell enlargement, and urinary tract diseases. J Cell Biol 2004; 167: 1195-1204.

20. Deng FM, Liang FX, Tu L, Resing KA, Hu P, Supino M et al. Uroplakin IIlb, a urothelia differentiation marker, dimerizes with uroplakin $\mathrm{lb}$ as an early step of urothelial plaque assembly. J Cell Biol 2002; 159: 685-694.

21. Peterson RS, Clevidence DE, Ye H, Costa RH. Hepatocyte nuclear factor-3 alpha promoter regulation involves recognition by cell-specific factors, thyroid transcription factor-1, and autoactivation. Cell Growth Differ 1997; 8: 69-82.

22. Kopachik W, Hayward SW, Cunha GR. Expression of hepatocyte nuclear factor-3alpha in rat prostate, seminal vesicle, and bladder. Dev Dyn 1998; 211: 131-140.

23. Wan H, Dingle S, Xu Y, Besnard V, Kaestner KH, Ang SL et al. Compensatory roles of Foxa1 and Foxa2 during lung morphogenesis. J Biol Chem 2005; 280: 13809-13816.

24. Hromas $R$, Costa $R$. The hepatocyte nuclear factor-3/forkhead transcription regulatory family in development, inflammation, and neoplasia. Crit Rev Oncol Hematol 1995; 20: 129-140.

25. Monaghan AP, Kaestner KH, Grau E, Schutz G. Postimplantation expression patterns indicate a role for the mouse forkhead/HNF-3 alpha, beta and gamma genes in determination of the definitive endoderm, chordamesoderm and neuroectoderm. Development 1993; 119: 567-578.

26. Jacob A, Budhiraja S, Reichel RR. Differential induction of HNF-3 transcription factors during neuronal differentiation. Exp Cell Res 1997; 234: 277-284.
27. Jacob A, Budhiraja S, Reichel RR. The HNF-3alpha transcription factor is a primary target for retinoic acid action. Exp Cell Res 1999; 250: 1-9.

28. Shimizu S, Kondo M, Miyamoto $Y$, Hayashi M. Foxa (HNF3) up-regulates vitronectin expression during retinoic acid-induced differentiation in mouse neuroblastoma Neuro2a cells. Cell Struct Funct 2002; 27: 181-188.

29. Enerback S, Ohlsson BG, Samuelsson L, Bjursell G. Characterization of the human lipoprotein lipase (LPL) promoter: evidence of two cis-regulatory regions, LP-alpha and LP. beta, of importance for the differentiation-linked induction of the LPL gene during adipogenesis. Mol Cell Biol 1992; 12: 4622-4633.

30. Fischer DF, Gibbs S, van De Putte P, Backendorf C. Interdependent transcription contro elements regulate the expression of the SPRR2A gene during keratinocyte terminal differentiation. Mol Cell Biol 1996; 16: 5365-5374.

31. Abdollahi A, Lord KA, Hoffman-Liebermann B, Liebermann DA. Interferon regulatory factor 1 is a myeloid differentiation primary response gene induced by interleukin 6 and leukemia inhibitory factor: role in growth inhibition. Cell Growth Differ 1991; 2: 401-407.

32. Yaar M, Karassik RL, Schnipper LE, Gilchrest BA. Effects of alpha and beta interferons on cultured human keratinocytes. J Invest Dermatol 1985; 85: 70-74

33. Saunders NA, Jetten AM. Control of growth regulatory and differentiation-specific genes in human epidermal keratinocytes by interferon gamma. Antagonism by retinoic acid and transforming growth factor beta 1. J Biol Chem 1994; 269: 2016-2022.

34. Lazzeri M. The physiological function of the urothelium - more than a simple barrier. Urol Int 2006; 76: 289-295.

35. Demerijan M, Man MQ, Choi EH, Brown BE, Crumrine D, Chang S et al. Topical treatment with thiazolidinediones, activators of peroxisome proliferator-activated receptor-gamma normalizes epidermal homeostasis in a murine hyperproliferative disease model. Exp Dermatol 2006; 15: 154-160

36. Stahlschmidt J, Varley CL, Toogood G, Selby PJ, Southgate J. Urothelial differentiation in chronically urine-deprived bladders of patients with end-stage renal disease. Kidney Int 2005; 68: 1032-1040.

37. Southgate J, Masters JR, Trejdosiewicz LK 2002 Culture of human urothelium. In Culture of Epithelial Cells, Freshney RI, Freshney MG (eds) New York: J Wiley and Sons Inc. pp 381-400.

38. Southgate J, Varley CL, Garthwaite MA, Hinley J, Marsh F, Stahlschmidt J et al. Differentiation potential of urothelium from patients with benign bladder dysfunction. BJU Int 2007; 99: 1506-1516.

39. Hall GD, Weeks RJ, Olsburgh J, Southgate J, Knowles MA, Selby PJ et al. Transcriptiona control of the human urothelial-specific gene, uroplakin la. Biochim Biophys Acta 2005 1729: $126-134$

40. Olsburgh J, Weeks R, Selby P, Southgate J. Human uroplakin lb gene structure and promoter analysis. Biochim Biophys Acta 2002; 1576: 163-170.

41. Zhang J, Ramesh N, Chen Y, Li Y, Dilley J, Working P et al. Identification of human uroplakin II promoter and its use in the construction of CG8840, a urothelium-specific adenovirus variant that eliminates established bladder tumors in combination with docetaxel. Cancer Res 2002; 62: 3743-3750.

42. Quandt K, Frech K, Karas H, Wingender E, Werner T. Matlnd and MatInspector: new fast and versatile tools for detection of consensus matches in nucleotide sequence data Nucleic Acids Res 1995; 23: 4878-4884.

43. Varley CL, Dickson AJ. Hepatocyte isolation stimulates formation of interferon stimulatory response element DNA-protein complexes. Biochem Biophys Res Commun 1999; 263 627-631.

44. Oottamasathien S, Wang Y, Williams K, Franco OE, Wills ML, Thomas JC et al. Directed differentiation of embryonic stem cells into bladder tissue. Dev Biol 2007; 304: 556-560.

\section{Supplementary Information accompanies the paper on Cell Death and Differentiation website (http://www.nature.com/cdd)}

